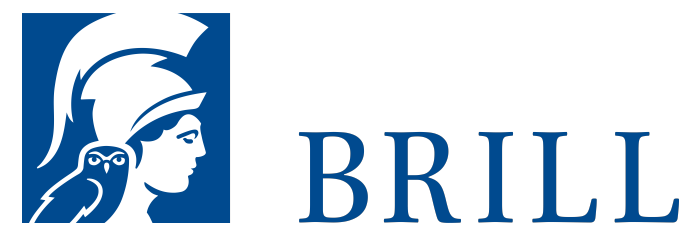

\title{
Emergent Mechanisms
}

\section{Reductive Explanation for Limited Beings}

Author: Ramiro Glauer

Is our mind explainable in terms of neural mechanisms? How we concieve of ourselves seems strongly to depend on how we respond to this question. In the present work an attempt at an affirmative answer is made. Currently, there are good reasons to believe that we can give a neural-mechanical explanation of how our mind works. In order to show this, first, a concept of mechanistic explanation is developed that is applicable to biological cognitive systems. This accomodates the fact that biological systems are usually complex, integrated systems that cannot be decomposed into a relatively small number of working parts like a clockwork. Complex biological mechanisms exhibit emergent behavior. The complexity of biological systems can be tackled with the aid of a number of methods of analysis. Models of a whole human brain are, for instance, well in reach that can be used to find integrated mechanistic explanations of cognitive capacities. Mind would thus be qualitatively reducible to neural mechanisms.

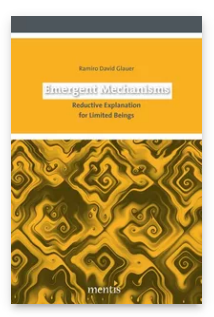

Pages: 217

Seiten

Language:

English

Subjects:

General,

Philosophy

Publisher: Brill | mentis

E-Book (PDF)

Released online:

o1 Oct 2012

ISBN: $978-3^{-}$

89785-952-4

List price

USD $\$ 52.00$

Paperback

Publication date:

o1 Oct 2012

ISBN: $978-3^{-}$

89785-777-3

List price

USD $\$ 52.00$ 
For more information see brill.com

Order information: Order online at brill.com +44330 333 0049 | customerservices@brill.com Submission information: brill.com/authors

Titles published by Brill | Fink, Brill | mentis or Brill | Schöningh: +49(o)715413279216| brill@brocom.de 